УДК 373.2.015.31:7

DOI:

Ірина Паласевич, кандидат педагогічних наук, доцент кафедри загальної педагогіки та дошкільної освіти Дрогобицького державного педагогічного університету імені Івана Франка

\title{
ЗАСОБИ ФОРМУВАННЯ ХУДОЖНЬО-ЕСТЕТИЧНОЇ КОМПЕТЕНТНОСТІ СТАРШИХ ДОШКІЛЬНИКІВ
}

У статті проаналізовано основні засоби формування художньо-естетичної компетентності стариих дошкільників, щуо охоплює емоційно-чуттєвий, пізнавальний, практичний, ціннісний та творчий компоненти, обтрунтовано, щчо своєчасне спілкування з творами різних видів мистеитва (образотворчого, музичного, літературного, театрального, декоративно-ужиткового тощо), введення дитини у світ краси $і$ гармоніі сприяють ї̈ художньо-естетичному розвитку; з'ясовано, щуо рівень художньо-естетичного розвитку старшого дошкільника визначається почуттям його задоволення від процесу і результатів власної творчої художньо-естетичної діяльності.

Ключові слова: естетичне виховання; художньо-естетичний розвиток; художньо-естетична компетентність; засоби формування художньо-естетичної компетентності; діти старшого дошкільного віку.

$\operatorname{Iim} 10$.

Iryna Palasevych, Ph.D.(Pedagogy), Associate Professor of the General Pedagogy and Preschool Education Department Drohobych Ivan Franko State Pedagogical University

\section{MEANS OF FORMATION OFTHE ARTISTIC-AESTHETIC COMPETENCE OFTHE SENIOR PRESCHOOLERS'}

The article analyzes the basic means of formation of the artistic-aesthetic competence of the senior preschoolers'; it is substantiated that the well-timed communication with works of various types of art, an introduction the child into the world of beauty and harmony are the important tasks of aesthetic education. Beauty is inseparable from kindness, it ennobles life, inspires for good deeds. An adult helps to find, feel and understand the beauty of poetry, music, and painting. Through art a child can understand more about everything in the surrounding world: nature, objects, work, and spiritual heritage.

The artistic-aesthetic development of children at different age stages has its own peculiarities, which determine the specifics of the organization of educational work in this direction. Peculiar to the children of certain age category the notions, skills (relative to various types of creative activity) are manifested in the formation of important components of the artistic-aesthetic competence: emotional-sensory (positive-emotional attitude to the surrounding world and works of art); cognitive component (ideas about different types of art and their features and means of expressiveness); practical (mastering the necessary artistic, creative skills, techniques of performing works); a value component (the presence of own aesthetic preferences, ratings and manifestation of artistic taste); creative (manifestation of initiative, autonomy and creativity).

It is determined that the level of the artistic-aesthetic development of a senior preschooler is manifested in a sense of satisfaction from the process and the results of creative artistic-aesthetic activities. This development is established by the art's influence on the growth of the aesthetic culture level of the child's personality, the level of aesthetic qualities and abilities, aesthetic experience and aesthetic attitude to the surrounding world, the process and the results of the child's creativity.

Keywords: an aesthetic education; an artistic-aesthetic development; an artistic-aesthetic competence; the means of formation of the artistic-aesthetic competence; thesenior preschoolers.

П остановка проблеми. Здатність сприймати й перетворювати дійсність за законами краси - обов'язковий елемент духовного багатства особистості. Без естетичної вихованості, сформованості естетичних почуттів, смаків, художніх здібностей неможливий різнобічний гармонійний розвиток. Тому дуже важливо відтоді, як людина починає сприймати навколишній світ, відкрити для неї всі прояви прекрасного, навчити бачити, відчувати й розуміти красу.

Найбільш сензитивним у цьому контексті $\epsilon$ старший дошкільний вік, коли збагачується емоційно-чуттєва сфера дитини, формується ії естетичне ставлення до життя, розвивається сприймання й розуміння прекрасного в мистецтві, природі, взаєминах людей. Власне у старшого дошкільника більш зрілими стають форми 
моральних, естетичних та пізнавальних почуттів (співчуття, чуйність, відповідальність, взаєморозуміння, переживання успіху-неуспіху, допитливість тощо).

Особливого ціннісного змісту набуває естетичне виховання у педагогічному процесі закладу дошкільної освіти. Звідси завдання вихователів - використовувати якомога більше засобів для формування художньо-естетичної компетентності дошкільників. Духовному й естетичному збагаченню малюків, формуванню якостей, необхідних для подальшого життя, сприяє залучення їх до різних видів творчої художньоестетичної діяльності. При цьому об'єктивна цінність кожного з них є різною, але вагомою для самої дитини.

Аналіз останніх досліджень і публікацій. Проблемі естетичного виховання, удосконалення його змісту, а також пошуку педагогічних технологій, спрямованих на формування художньо-естетичної компетентності дітей дошкільного віку, присвячено наукові розвідки А. Богуш, I. Большакової, I. Казмерчук [3], Ю. Клокової [4], С. Костюк, Н. Лисенко, С. Матвієнко [5], Т. Пагути, М. Федорової [3], А. Шевчук [10] та ін. Усі вони розглядають естетичне виховання дошкільників як системну діяльність, спрямовану на розвиток умінь сприймати й оцінювати явища навколишньої дійсності за законами краси; збагачувати у процесі їх сприймання свій внутрішній світ, творити красу у природному і соціальному довкіллі, примножувати іiі результатами власної естетично значущої діяльності.

Дослідниці І. Казмерчук та М. Федорова виокремлюють такі завдання естетичного виховання дітей дошкільного віку: систематично розвивати сприймання прекрасного, естетичні почуття й уявлення дітей; залучати малят до діяльності у сфері мистецтв, виховуючи в них потребу і звичку посильно вносити елементи прекрасного в побуг, природу і суспільні відносини; формувати основи естетичного смаку і здатність самостійно оцінювати твори мистецтва та явища життя; розвивати художньо-творчі здібності дітей [3, $109-110]$.

Як стверджує С. Матвієнко, у дошкільному віці естетичне сприймання має специфічний характер, обумовлений віковими особливостями, i вирізняється емоційною безпосередністю, підвищеним інтересом до довкілля, живим відгуком при зустрічі 3 прекрасним та дивовижним, а також намаганням надати йому естетичну оцінку $[5,72]$.

Естетичне виховання, на думку І. Савіцької, передбачає формування у дітей естетичного ставлення до мистецтва, розвиток у них художніх потреб і здатності до творчості. Дослідниця наголошує, що творча художньо-естетична діяльність-це насамперед відмова від стереотипів сприйняття та відображення, постійний пошук тем, ідей, аспектів і засобів їх реалізації в мистецтві. Загалом мету творчості вона визначає як прагнення до реалізації потреби самовираження й естетичного освоєння світу. У сфері естетичної діяльності творчість стає засобом досягнення поставленої мети [7]. Зі свого боку, А. Шевчук підкреслює, що у мистецькій або художній активності, спрямованій на творчу взаємодію $з$ навколишнім середовищем та іншими людьми, проявляються елементи особистісної естетичної культури дитини $[10,15]$.

Актуальність проблеми та недостатнє іiі розв'язання зумовили вибір теми пропонованої статті, метою якої $є$ аналіз основних засобів формування художньо-естетичної компетентності дітей старшого дошкільного віку.

Виклад основного матеріалу. У старших дошкільників $\epsilon$ всі необхідні передумови для формування елементарної художньо-естетичної компетентності. Їм доступне розуміння різнобічних цінностей; вони ознайомлюються 3 різними видами мистецтва (образотворчого, музичного, театрального, літературного). Крім цього, діти вказаного віку здатні емоційно відгукуватися на прояви естетичного у житті й мистецтві, виражати свої почуття у різних видах мистецької діяльності. До того ж вони можуть оцінити власні вчинки та вчинки інших, знають правила й норми поведінки. У дошкільників усе більш увиразнюються основи естетичного смаку (чуття лінії, форми, кольору, ритму тощо).

Дитина володіє окремими вродженими рисами, що сприяють формуванню естетичних здібностей: безпосередністю, емоційністю, щирістю, відкритістю до світу, багатою уявою, фантазією. Усім своїм єством вона прагне до естетичного самовираження. У дитинстві естетичні здібності розвиваються в міру збільшення естетичних потреб. Поступово виокремлюється духовна потреба в естетичних переживаннях. Педагогам слід розвивати ії разом iз формуванням здібностей до естетичної діяльності. Така “естетична зустріч” здібностей iз потребами максимально сприяє розвитку творчості й виробленню художньо-естетичного смаку дитини [4, 267].

Дослідники Л. Одерій та А. Роздимаха визначають естетичну здібність як сукупність індивідуально-психологічних особливостей 
особистості, через які відкривається можливість здійснювати творчу естетичну діяльність. Своєрідним проявом, конкретизацією i спеціалізацією естетичних здібностей є художні здібності, тобто здатність не тільки до естетичного сприймання, переживання й оцінювання творів мистецтва, а й до створення певної художньої цінності. Художньо-естетичні здібності виявляються у схильності, потребі, можливості, здатності до художньої діяльності, у легкості засвоєння дитиною навичок творчої діяльності [6].

Під художньо-естетичним розвитком дошкільника розуміємо процес постійних якісних змін у ставленні до дійсності й мистецтва як результат цілеспрямованих педагогічних впливів закладу дошкільної освіти, сім'ї та інших соціальних інститутів, що здійснюється через навчання, виховання й самовиховання. Уведення дитини до світу краси й гармонії $є$ важливим завданням естетичного виховання. Як відомо, краса невіддільна від доброти, облагороджуючи життя, надихаючи людину у всіх її справах. Дорослий допомагає дитині знайти, відчути i зрозуміти красу поезії, музики, живопису, а через мистецтво - глибше осягнути все іiі довкілля: природу, предмети, взаємини, а також працю, духовні надбання.

Дошкільнику треба пояснити, що у світі існує не тільки потрібне, корисне, а й красиве. Вихователеві необхідно навчити малюків бачити, розуміти, відчувати і переживати красу. На думку В. Сухомлинського, краса - могутній засіб виховання чутливості душі. Як наголошував педагог, без розуміння і відчуття прекрасного, без захоплення і натхнення ніколи не стати справжньою людиною, не навчитися боротися зі злом. "Краса - це яскраве світло, що осяває світ, виправляє наш дух, нашу совість, наші почуття й переконання. Через неї відкриваються істина, правда, добро" [8, 410].

Зазначимо, що у програмах розвитку, навчання й виховання дітей дошкільного віку окремий розділ присвячено художньо-естетичному та креативному розвитку, починаючи з раннього віку. Художньо-естетична складова представлена такими видами роботи: читання й розповідання художніх творів, інсценування та драматизація за змістом творів художньої літератури, музика, образотворча діяльність. Виконання завдань розділу “Креативний розвиток" забезпечує розвиток творчих здібностей дітей, їх уяви, самостійності у втіленні задуму, пошуку шляхів його реалізації. Для цього пропонується залучення вихованців ЗДО до різних видів роботи: інсценування, драматизація твору з його творчим переосмисленням, втілення творчого задуму в образотворчій діяльності, виготовлення виробів із різноманітних матеріалів, етюди, пантоміми, пошуково-дослідницька діяльність під час ознайомлення із природою тощо [1].

Як стверджують науковці, художньоестетичний розвиток дітей на різних вікових етапах має свої особливості, які визначають специфіку організації освітньої роботи 3 цього напряму. Притаманні малятам певної вікової категорії важливі уявлення, вміння, навички, що стосуються різних видів творчої діяльності, проявляються у сформованості важливих складових художньо-естетичної компетентності, a саме:

- емоційно-чуттєвої (позитивно-емоційне ставлення до навколишнього світу та творів мистецтва);

- пізнавальної (уявлення про різні види мистецтва та їх особливості й засоби виразності);

- практичної (оволодіння необхідними художніми, творчими вміннями, техніками виконання робіт);

- ціннісної (наявність власних естетичних уподобань, оцінок та проявів художнього смаку);

- творчої (прояви ініціативності, самостійності та креативності) $[2,11]$

Формування художньо-естетичної компетентності дітей відбувається в різних видах художньоестетичної діяльності: на заняттях 3 образотворчого, декоративно-ужиткового мистецтва, музики, хореографії; при ознайомленні 3 творами художньої літератури; при відвідуванні театру, музею; упродовж спілкування з природою тощо. Старший дошкільник здатен передавати своє ставлення до різних видів мистецтва; орієнтується у назвах його основних видів (живопис, графіка, скульптура, архітектура, декоративно-ужиткове); в одному-двох жанрах, наприклад, образотворчого мистецтва (пейзаж, портрет) та назвах предметів, пов'язаних з образотворчою діяльністю; називає деякі види образотворчої діяльності (вишивка, витинанка, різьблення, писанкарство, килимарство тощо); вживає слова на позначення відповідних дій (домалювати, розфарбувати, вирізати, склеїти тощо); називає відтінки кольорів. Дошкільник бере на себе ролі “художника”, “скульптора”, “майстра", “конструктора", відповідно мотивує вибір діяльності та матеріалів, передає характерні ознаки предметів (форму, пропорції, колір, фактуру, величину) [1].

У міру розвитку вихованців усе більше ускладнюються композиції дитячих малюнків, 
аплікацій, ліплення, конструювання предметів та навколишньої дійсності. Дитина активно і творчо виражає емоційне ставлення до них, причому іiі творчість приваблює щирістю почуттів та яскравістю барв. Старшому дошкільникові стає дедалі цікавіше творити разом 3 однолітками, визначати участь кожного в загальній композиції, створювати художній образ, завдяки чому малюнок як продукт творчих зусиль набуває оригінальності та неповторності. Дитина відображає в малюнку характерні риси персонажів (добрий, веселий, злий); виділяє в ліпленні, аплікації та конструюванні реальне і казкове, типове й особливе; помічає недоліки у своїх роботах; може естетично оцінити кінцевий результат своїх художніх зусиль.

Старший дошкільник захоплено й емоційно слухає музику; визначає загальний характер і настрій музичного твору; асоціює певний музичний образ із власним світосприйняттям. У значної більшості дітей у цей період зростає здатність індивідуально інтерпретувати, розвиваються музичні здібності, виникає бажання навчитися гри на музичних інструментах. Майбутній школяр цілісно характеризує музичний твір; розрізняє властивості звуку, окремі засоби виразності; диференціює різні жанри музичного мистецтва, поєднує його 3 танцювальними рухами; складає про почугі мелодії казки, вірші, коротенькі оповідання тощо.

Батькам і педагогам необхідно виважено ставитися до вибору дитиною бажаних для прослуховування музичних творів, пропонувати іiі увазі не лише легку, ритмічну дорослу музику, а й класичну та дитячу. Дорослим слід вправляти дошкільника у визначенні жанру музичного твору, називанні інструмента, на якому він виконується; відгадуванні п’єс, включених до музичної вікторини. Доцільно широко використовувати музику в аудіо- та відеозаписах; організовувати перегляд доступних дітям за змістом оперних i балетних вистав, відвідування концертів, музеїв [1, 233 - 234]. Важливо навчати дитину розрізняти “музику природи" - співи птахів, звуки різних комах, шелест листя дерев та хвиль води тощо, порівнювати природнумузикузі створеними людьми мелодіями, знаходити в них спільне й відмінне.

У різних сферах життєдіяльності дорослі використовують високохудожню музику 3 яскравими образами, різними настроями, під яку можна по-різному відтворювати ходьбу, біг, стрибки, рухи рук тощо. Потрібно використовувати музично-рухову імпровізацію в сюжетних етюдах задля стимулювання індивідуальних творчих проявів дитини.

Старший дошкільник володіє такими вміннями й навичками: а) у сприйманні театрального мистецтва: розуміє зміст дійства вистави, театральний образ як живу акторську дію 3 використанням засобів мовлення, міміки, жестів, рухів, музики, танцю, співу; співпереживає героям сюжету, підказує, як їм поводитися у скрутних ситуаціях; оцінює свої вчинки та вчинки ровесників, порівнюючи з учинками персонажів вистави; наслідує позитивних героїв вистави; впізнає в силуетах і тінях характерні образи персонажів; оцінює героїв (хитрий, жадібний, нерозумний, довірливий); б) в ігровій діяльностівідображає характерні особливості образу театральних персонажів; своєчасно долучається до групової драматизації фрагментів твору; ініціює організацію ігор у “театр"; в) у сценічній діяльності - бере активну участь у підготовці театралізованих ігор; творчо перевтілюється в образи персонажів, розігрує сюжети, виразно та 3 гумором виконує ролі; вносить творчі фрагменти у гру за казкою; виготовляє декорації, атрибути, костюми; ініціює організацію ігор-драматизацій, театралізованих ігор, заохочуючи однолітків до розігрування сюжетів літературних творів, казок [1, 237 - 239].

Дитина старшого дошкільного віку орієнтується у варіативності театрів (пальчиковий, настільний, театр іграшок, тіньовий театр, ляльковий театр, театр картинок); розуміє особливості й відмінності між ними; театральну термінологію (три блоки: актори - актор, трупа, режисер, костюмер, гример, художник, глядачі, успіх, оплески; вистава - сюжет, сценарій, прем'єра, частина, антракт, фінал; театр - афіша, каса, квиток, зала, куліси, дзвінок, завіса, балкон, декорації). Вихованці свідомо ставляться до засвоєння знань про театр як вираження життєвих ситуацій в акторській грі; отримують уявлення про різні види театру, їхні особливості, призначення $[2,38]$

Вагомий вплив на формування художньоестетичної компетентності старших дошкільників мають естетичні фактори довкілля: дизайн будівлі дитячого садка, ділянка 3 їі обладнанням та зеленими насадженнями, предметне середовище (дизайн кімнати, меблі, іграшки). Своїм зовнішнім виглядом, гармонією ліній і форм, кольором, розмаїттям змісту вони сприяють виробленню естетичного сприймання, естетичних почуттів, оцінок, основ естетичного смаку. Красиве різноманітне колірне вирішення інтер'єру приміщень, комплектні меблі для дітей і дорослих, текстильний декор, забезпечення дитячої діяльності сучасними засобами, посібниками, матеріалами матимуть позитивний вплив на естетичне виховання дітей. 
Важливість поєднання художньої праці і дизайну як необхідного засобу художньоестетичного виховання обгрунтовує С. Матвієнко, рекомендуючи використовувати такі види дизайну: дизайн для дітей (створення дорослими для дитини комфортного матеріального середовища) і дитячий дизайн (художня праця) [5].

Дитячий дизайн - це вид художньоконструктивної діяльності дітей дошкільного віку, орієнтований на розвиток їхніх естетичних здібностей і практичних умінь художнього конструювання. Ідеться про заняття 3 художньої праці й дизайну, які розвивають у старших дошкільників інтелект, культуру мовлення і спілкування, здібності до аналізу й узагальнення, творчі здібності - просторову уяву, проектнообразне мислення. Діти починають усвідомлювати своє співавторство, авторську компетентність, беручи участь у створенні естетичних об'єктів, пробують упорядковувати побут, використовуючи набутий у закладі дошкільної освіти досвід дизайну. Вихованці граються в “одягання ляльок”, у “дочки-матері”, облаштовують ігрові кімнати й будиночки, будують “фортеці” та “замки”. Вони моделюють прикраси й сувеніри, майструють одяг для ляльок, костюми й декорації до своїх спектаклів і дитячих свят. Усе це потребує ручної праці, до якої діти охоче беруться, прагнучи зробити все красиво, зі смаком, охайно та старанно. Продукти дитячої дизайн-творчості можуть бути використані дошкільниками одразуж після закінчення роботи, а також в іграх та побуті. При цьому дитина повніше відчуває себе творцем, пізнає свою індивідуальність, рівень умінь, порівнюючи власні вироби з роботами однолітків (за стилістикою, творчою манерою-почерком).

Незамінним засобом формування художньоестетичної компетентності дітей дошкільного віку $€$ природа. Виростаючи серед неї, дитина вчиться бачити гармонійність, красу, багатство барв кожної пори року, відтворювати свої враження в усній розповіді, малюнках.

Спілкування з природою сприяє розвиткові не лише естетичного смаку, а й мовлення. Адже заняття на лоні природи - це ті хвилини, коли педагог “торкається” до дитячого серця красою рідного краю, рідного слова. Усе це спонукає вихованців бачити, сприймати та переживати красу мови і природи упоєднанні кольорів і звуків, прагнення передати свої думки та враження у фарбах.

Забезпечити глибше переживання краси довкілля, пробудження образного мислення дітей допоможуть оцінно-творчі завдання, наприклад: вербальні - добір порівнянь (“Що нагадує листопад?” “На що схожа кульбаба?”); віршування за пропонованими римами; придумування монологів об'єктів природи (“Я найшвидший струмочок весни"; "Не топчіть мене, тендітну сніжинку”); конструювання діалогів з об'єктами та явищами природи (“Моя розмова з квіткою”; “Добрий день, весно” та ін.); музично-пластичні - “Склади пісеньку весняного дощику”; “Затанцюй танок листопаду”; “Передай рухами народження підсніжника" тощо [9, 16-17].

Висновки. Підсумовуючи усе зазначене, можемо констатувати, що важливими засобами формування художньо-естетичної компетентності старших дошкільників є мистецтво (образотворче, музичне, літературне, театральне, декоративно-ужиткове та ін.), дитячий дизайн, природа. Розглядаючи твори мистецтва й милуючись ними, малюк прагне передати свої почуття словами, інтонацією, а бажання відтворити їх у видимих образах спонукає взятися за олівець, пензель, музичний інструмент. У дітей розвиваються творчість, фантазія, активність, самостійність, спостережливість. Тому дорослим слід стимулювати потребу дошкільника в осмисленні краси об'єктів і явищ природи, творів мистецтва, продуктів творчої естетичної діяльності. Це сприятиме його художньоестетичному розвитку, удосконаленню здібностей, формуванню художніх смаків, поглядів, естетичному сприйманню світу.

Проведене дослідження не вичерпує всіх аспектів розглядуваної проблеми. Перспективними напрямами подальших досліджень вважаємо аналіз змісту та технологій підготовки майбутніх вихователів до формування художньо-естетичної компетентності дітей дошкільного віку.

\section{ЛІТЕРАТУРА}

1. Білан О.І. Українське дошкілля : програма розвитку дитини дошкільного віку / O.І. Білан, Л.М. Возна, О.Л. Максименко та ін. - Тернопіль: Мандрівець, 2013. - 264 с.

2. Борщ Р.М. Радість творчості: програма художньо-естетичного розвитку дітей раннього та дошкільного віку / Р.М. Борщ, Д.В. Самойлик. Тернопіль: Мандрівець, 2013. - 72 с.

3. Казмерчук I. Естетичне виховання дошкільників засобами природи / I. Казмерчук, М. Федорова // Інноваційний досвід педагогів дошкільної та початкової освіти Житомирщини: зб. наук.-метод. пр. / за заг. ред. В.С. Литньова, Н.С. Колесник. - Житомир, 2012. - С. 107 - 110.

4. Клокова Ю. Формування художньоестетичного смаку в дошкільників / Ю. Клокова / 
/ Вісник Інституту розвитку дитини (додаток): методичні та практичні матеріали. - Вип. 2. Київ, 2011. - С. 265 - 268.

5. Матвієнко C.I. Художня праця та основи дизайну: навч. посіб. / С.І. Матвієнко. - Ніжин: Вид-во НДУ ім. М. Гоголя, 2016. - 201 с.

6. Одерій Л. Розвиток художніх та естетичних здібностей дітей старшого дошкільного віку / Л. Одерій, А. Роздимаха // Актуальні проблеми психолого-педагогічного та соціального супроводу дитини на ранніх етапах соціалізації. Гуманізація навчально-виховного процесу. - Спецвипуск 4. Част. 1. - Слов'янськ, 2010. - С. 217 - 222.

7. Савіцька I. Ю. Художньо-естетичний розвиток учнів молодших школярів засобами мистецтва (на прикладі Харківського ліцею мистецтв № 133) / І.Ю. Савіцька. - [Електронний pecypc]. - Режим доступу: http://tme.umo.edu.ua/ docs/Dod/2_2010/savitska.pdf

8. Сухомлинський В.О. Вибрані твори: в 5-ти т. / В.О. Сухомлинський. - К., 1976, т. 2. - С. 410.

9. Тарасенко Г. Формування у дошкільників гуманно-особистісного ставлення до природи: аксіологічний аспект / Г. Тарасенко // Актуальні проблеми дошкілля: зб. наук. праць / за ред. Марії Чепіль. - Дрогобич: РВВ ДДПУ ім. І. Франка, 2012. - С. 13 - 20.

10. Шевчук А. Дитина у світі культури: орієнтири до освітньої лінії / А. Шевчук // Дошкільне виховання. - 2012. - № 9 . - С. 15 - 21 .

\section{REFERENCES}

1. Bilan, O.I., Vozna, L.M., Maksymenko, O.L. et al. (2013). Ukrainske doshkillia: prohrama rozvytku dytyny doshkilnoho viku [Ukrainian preschool: a program for the development of a child of preschool age]. Ternopil: Mandrivets Publ, 264 p. [in Ukrainian].

2. Borshch, R.M. \& Samoilyk, D. V. (2013). Radist tvorchosti: prohrama khudozhnoestetychnoho rozvytku ditei rannoho ta doshkilnoho viku [Joy of creativity: program of artistic-aesthetic development of children of early and preschool age]. Ternopil: Mandrivets Publ., 72 p. [in Ukrainian].

3. Kazmerchuk, I. \& Fedorova, M. (2012).
Estetychne vykhovannia doshkilnykiv zasobamy pryrody [Aesthetic upbringing of preschoolers by means of nature]. Innovative experience of teachers of preschool and primary education of Zhytomyr region. Zhytomyr, pp. $107-110$. [in Ukrainian].

4. Klokova, Yu. (2011). Formuvannia khudozhnoestetychnoho smaku $\mathrm{v}$ doshkilnykiv [Formation of artistic-aesthetic taste of preschoolers]. Bulletin of the Institute for the Development of the Child (addition): methodical and practical materials. vol. 2, Kyiv. pp. 265 - 268. [in Ukrainian].

5. Matviienko S. I. (2016). Khudozhnia pratsia ta osnovy dyzainu [Artwork and design basics]. Nizhyn: NDU im. M. Hoholia Publ., 201 p. [in Ukrainian].

6. Oderii, L. \& Rozdymakha, A. (2010). Rozvytok khudozhnikh ta estetychnykh zdibnostei ditei starshoho doshkilnoho viku [Development of artistic and aesthetic abilities of children of the senior preschool age]. Actual problems of psycho-pedagogical and social support of the child in the early stages of socialization. Humanization of the educational process. vol. 4, part 1, Slovyansk. pp. 217 -222. [in Ukrainian].

7. Savitska, I. Iu. Khudozhno-estetychnyi rozvytok uchniv molodshykh shkoliariv zasobamy mystetstva [Artistic and aesthetic development of pupils of junior pupils by means of art]. [Electronic resource]. Available at: http://tme.umo.edu.ua/docs/Dod/2 2010/ savitska.pdf [in Ukrainian].

8. Sukhomlynskyi, V.O. (1976). Vybrani tvory: v 5-ty $t$. [Selected works: in 5 t.]. Kyiv, vol. 2. p. 410. [in Ukrainian].

9. Tarasenko, H. (2012). Formuvannia u doshkilnykiv humanno-osobystisnoho stavlennia do pryrody : aksiolohichnyi aspekt [Formation in preschoolers of a humane-personal approach to nature: an axiological aspect]. Actual problems in preschool. Drohobych: RVV DDPU im. I. Franka Publ., pp. 13 - 20. [in Ukrainian].

10. Shevchuk, A. (2012). Dytyna u sviti kultury: oriientyry do osvitnoi linii [Child in the world of culture: guidelines for the educational line]. Preschool education. No. 9, pp. 15 - 21. [in Ukrainian].

\section{Стаття надійшла до редакції 15.09.2018}

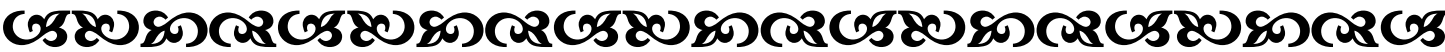

"Будь-яқе навчання людини, єне що інше, яклистеитво сприяти прагненню природи до свого власного розвитку”.

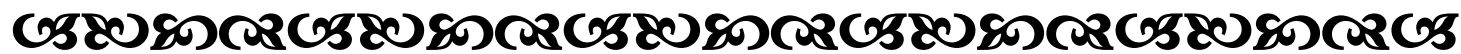

